\title{
MORPHOGENIC AND STRUCTURAL CHARACTERISTICS OF MARANDU GRASS AFFECTED BY FERTIGATION WITH TREATED SEWAGE EFFLUENT AND CUTTING HEIGHT
}

\author{
Geffson de F. Dantas ${ }^{1 *}$, Rogério T. de Faria ${ }^{2}$, Natã R. Costa ${ }^{2}$, \\ Gilmar O. Santos ${ }^{3}$, Antonio S. Ferraudo 2
}

${ }^{1 *}$ Corresponding author. UNIARA/ Araraquara - SP, Brasil.

E-mail: geffson@hotmail.com | ORCID ID: https://orcid.org/0000-0003-3949-7723

\section{KEYWORDS}

defoliation, nitrogen, water reuse.

\begin{abstract}
The response of biomass flow components of forage from the interaction between fertigation with wastewater and cutting height during the year is little known. The objective of this work was to verify the responses of morphogenic and structural characteristics of Urochloa brizantha as a function of fertigation application strategies with sewage treatment plant effluent (TSE), complemented with urea (U), associated with harvest with two plant heights during the dry and rainy periods. The forage cutting heights were $30 \mathrm{~cm}\left(\mathrm{H}_{1}\right)$ and $40 \mathrm{~cm}\left(\mathrm{H}_{2}\right)$, and nitrogen fertilization doses were $9.1\left(\mathrm{D}_{1}\right), 12.1\left(\mathrm{D}_{2}\right)$, $22.5\left(\mathrm{D}_{3}\right), 26.6\left(\mathrm{D}_{4}\right)$, and $34.0\left(\mathrm{D}_{5}\right) \mathrm{kg}$ of $\mathrm{N}$ per $\mathrm{Mg}^{-1}$ of dry matter $(\mathrm{DM})$ produced, applied by TSE via fertigation, plus $7.5 \mathrm{~kg} \mathrm{~N}$ per $\mathrm{Mg}^{-1}$ of DM produced, applied in the form of urea by cover in all treatments. Factor analyses for the dry and rainy periods identified two processes that correspond to forage mass growth and leaf development. Analysis of variance showed that treatments $\mathrm{D}_{5} \mathrm{H}_{2}$ and $\mathrm{D}_{5} \mathrm{H}_{1}$ presented superior responses over the other treatments, in the dry, and rainy periods. The treatment $\mathrm{D}_{5} \mathrm{H}_{2}$ stood out in the process of forage mass growth, and $\mathrm{D}_{5} \mathrm{H}_{1}$ in leaf development.
\end{abstract}

\section{INTRODUCTION}

Pastures of the genus Urochloa are spread throughout the tropics, due to the varied growth according to habitat (Cezário et al., 2015). Its expansion is a result of higher pest resistance and better animal performance compared with native pastures (Macedo et al., 2014). Among the different species of forage plants cultivated in Brazil, one that stands out is Urochloa brizantha, which, besides being the most cultivated in the country, has the largest volume of seeds destined for export (Silva et al., 2014).

The main limitation on the production of tropical forages in regions whose winter is characteristically dry and cold is irregular production with good nutritional value during the year, which is determined by limiting air temperature, water, and luminosity during winter. Because production is irregular at this time of year, cattle ranchers commonly do not use fertilizers, especially those with nitrogen sources, because of low water availability, resulting in low soil fertility.

The supply of nutrients through fertilizer application is important in the growth of forages. Nitrogen $(\mathrm{N})$ is the most important nutrient to maximize and maintain the dry mass productivity of forage plants (Galindo et al., 2017), provided that other production factors are not limiting (Marchetti et al., 2018).

Because of high water consumption and the high cost of nutrients, fertigation with effluent from treated sewage treatment plant (TSE) is a promising alternative for most crops, especially forage crops, because it is rich in nitrogen and phosphorus, and its use for fertigation reduces or eliminates the addition of fertilizers (Moyo et al., 2015).

The morphogenesis aids to describe the dynamics of the generation and expansion of the tissues and organs of the plant in time and space, summarized by the variables: leaf appearance rate (LApR), leaf elongation rate (LEIR),

\footnotetext{
${ }^{2}$ FCAV - UNESP/ Jaboticabal - SP, Brasil.

${ }^{3}$ UniRV/ Rio Verde - GO, Brasil.

Area Editor: Adunias dos Santos Teixeira

Received in: 5-17-2019

Accepted in: 9-1-2020
} 
pseudostem elongation rate (PEIR), leaf life duration (LLD), and leaf senescence rate (LSenR), which, despite their genetic nature, are strongly influenced by environmental conditions (temperature, water and soil fertility) and management strategies (Costa et al., 2017). The interactions between these variables determine the structural characteristics such as the number of live and dead leaves per pseudostem (LLN and DLN), leaf blade length (LBL), and pseudostem length (PL).

Biomass accumulation also depends on plant defoliation because of the frequency of grazing, where the forage is harvested at a certain height. This management affects productivity and its components such as leaf, stem and dead material, and aims to achieve high productive potential and nutritional value throughout the year (Silva et al., 2016). The adoption of Brachiaria cutting height as a management strategy may be advantageous because of the ease of controlling the entry and exit of animals in the pickets, as it considers the chronological age of the pasture. However, its morphogenesis, which depends on the conditions of the environment, stimulates desirable characteristics such as increased leaf appearance rate, leaf elongation, and the number of live leaves per tiller. The adoption of management with fixed days, depending on the time of year, can stimulate the increase in the rate of stem elongation, leaf senescence, leaf life, and number of dead leaves per tiller, which are considered undesirable characteristics because they cause low forage quality and grazing efficiency.

The literature lacks information on the annual morphophysiological behavior of Brachiaria-type forages in response to fertigation with TSE, associated with mineral fertilization, and cutting management based on canopy height, especially in regions with climatic seasonality, to manage crops. The hypothesis tested in this research is that both the desirable morphogenic characteristics (LApR and LEIR) and structural characteristics (LLN) can be increased with the adoption of cutting height and adequate nitrogen supply during the year.

In this context, the objective was to determine the effects on the morphogenic and structural characteristics of Urochloa brizantha as a function of the application of nitrogen dose via TSE supplemented with nitrogen (urea), associated with harvests with two canopy heights, during the dry (autumn-winter) and rainy (spring-summer) periods.

\section{MATERIAL AND METHODS}

\section{Experimental area characteristics}

The experiment was conducted at the Experimental Farm of FCAV-UNESP, in Jaboticabal, SP (latitude $21^{\circ} 15^{\prime} \mathrm{S}$, longitude $48^{\circ} 18^{\prime} \mathrm{W}$ and altitude of $545 \mathrm{~m}$ ), for one year, from February 2015 to February 2016. The climate of the region, according to the Köppen-Geiger classification, is of type Aw, tropical, with a precipitation of $1,425 \mathrm{~mm}$, concentrated in summer, and average annual temperature of $22.2{ }^{\circ} \mathrm{C}$ (Alvares et al., 2013).

The soil of the experimental area is the typical eutrophic Red Latosol (Oxisol), with very clayey texture (Santos et al., 2013), whose chemical attributes in the 0$0.20 \mathrm{~m}$ layer are: $\mathrm{pH}\left(\mathrm{CaCl}_{2}\right) 5.4 ; 26 \mathrm{~g} \mathrm{~kg}^{-1}$ of $\mathrm{Mo} ; 68 \mathrm{~g}$ $\mathrm{dm}^{-3}$ of $\mathrm{P}$ (resin); $5.9 \mathrm{mmol}_{\mathrm{c}} \mathrm{dm}^{-3}$ of $\mathrm{K} ; 31.5 \mathrm{mmol}_{\mathrm{c}} \mathrm{dm}^{-3}$ of $\mathrm{Ca} ; 16.5 \mathrm{mmol}_{\mathrm{c}} \mathrm{dm}^{-3}$ of $\mathrm{Mg} ; 32.5 \mathrm{mmol}_{\mathrm{c}} \mathrm{dm}^{-3}$ of $\mathrm{H}+\mathrm{Al}$; and $62 \%$ of $\mathrm{V}$.

\section{Experimental design}

The experimental design was in randomized blocks with a subdivided plot, with a dose of nitrogen fertilization in the plot and cutting height in the subplot, in four replications, totaling 40 experimental units, each with an area of $4.8 \mathrm{~m}^{2}(2.4 \times 2 \mathrm{~m})$ (Figure 1). A total of ten treatments were evaluated, corresponding to the association of two forage cutting heights with five doses of nitrogen fertilization. The cutting heights were $30 \mathrm{~cm}\left(\mathrm{H}_{1}\right)$ and $40 \mathrm{~cm}$ $\left(H_{2}\right)$. Nitrogen fertilization doses were: $\mathrm{D}_{1}=9.1, \mathrm{D}_{2}=12.1$, $\mathrm{D}_{3}=22.5, \mathrm{D}_{4}=26.6$, and $\mathrm{D}_{5}=34.0 \mathrm{~kg}$ of $\mathrm{N}$ per $\mathrm{Mg}^{-1}$ of dry matter $(\mathrm{DM})$ produced in the treatment $\mathrm{D}_{3} \mathrm{H}_{1}$, assumed as reference (Figure 2). The nitrogen fertilization doses corresponded to the application of TSE at different concentrations $\left(\mathrm{C}_{1}\right.$ to $\left.\mathrm{C}_{5}\right)$, complemented with urea (U). The TSE was applied with the following concentrations of the effluent in water: $\mathrm{C}_{1}=11 \%, \mathrm{C}_{2}=31 \%, \mathrm{C}_{3}=60 \%, \mathrm{C}_{4}=87 \%$, and $\mathrm{C}_{5}=100 \%$ of the applied depth. Urea complementation was equivalent to $1 / 3$ of the total amount of nitrogen applied (22.5 $\mathrm{kg} \mathrm{ha}^{-1}$ of $\mathrm{N}$ per $\mathrm{Mg}^{-1}$ of $\mathrm{DM}$ produced) in the reference treatment $\left(\mathrm{D}_{3} \mathrm{H}_{1}\right)$, with the same complementation in the other treatments (Figure 2). 


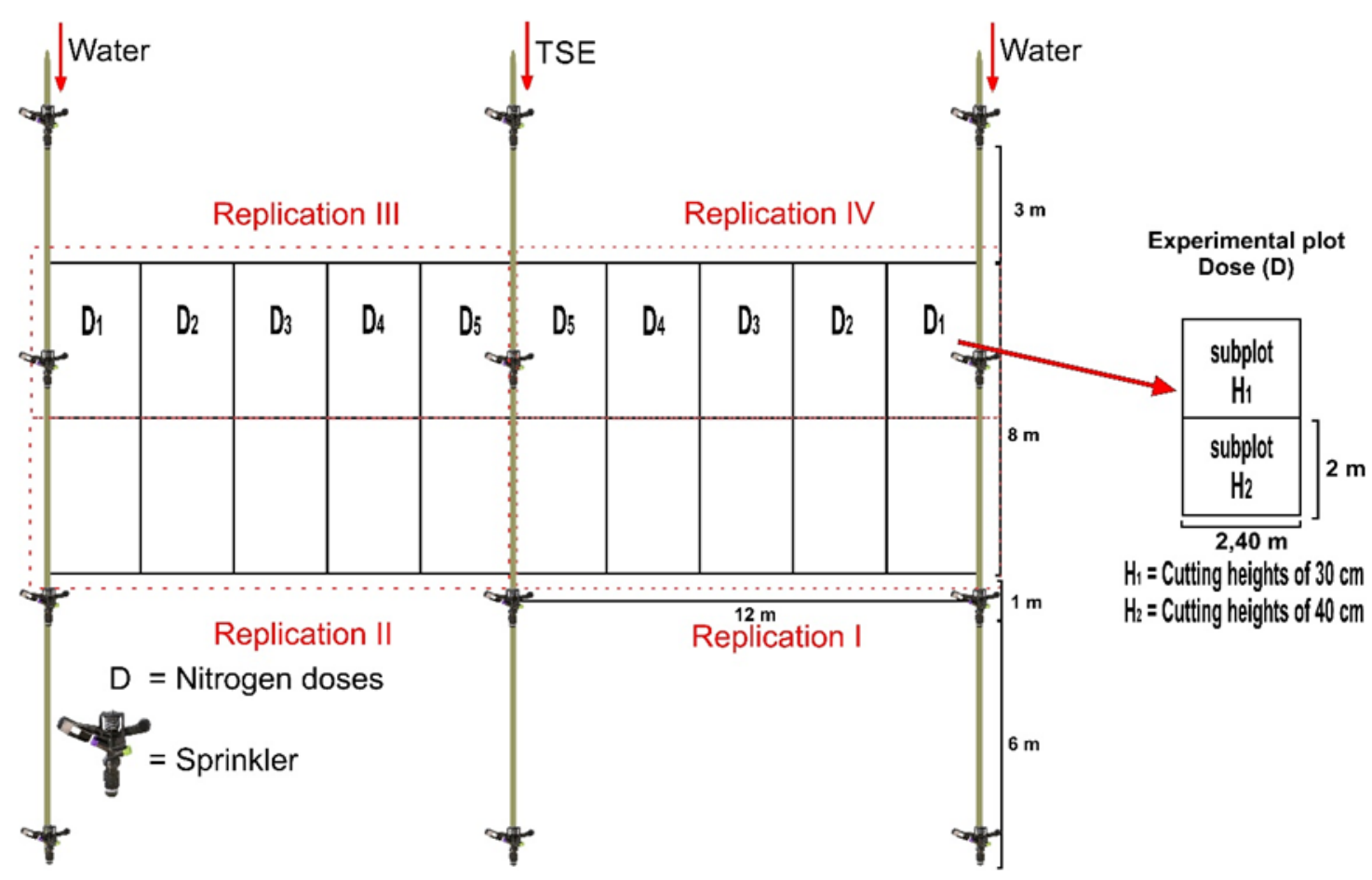

FIGURE 1. Experimental scheme with water and treated sewage effluent (TSE) distribution lines, and experimental units with treatments by nitrogen doses $\left(\mathrm{D}_{1}\right.$ to $\left.\mathrm{D}_{5}\right)$ and cutting heights $\left(\mathrm{H}_{1}\right.$ and $\left.\mathrm{H}_{2}\right)$.

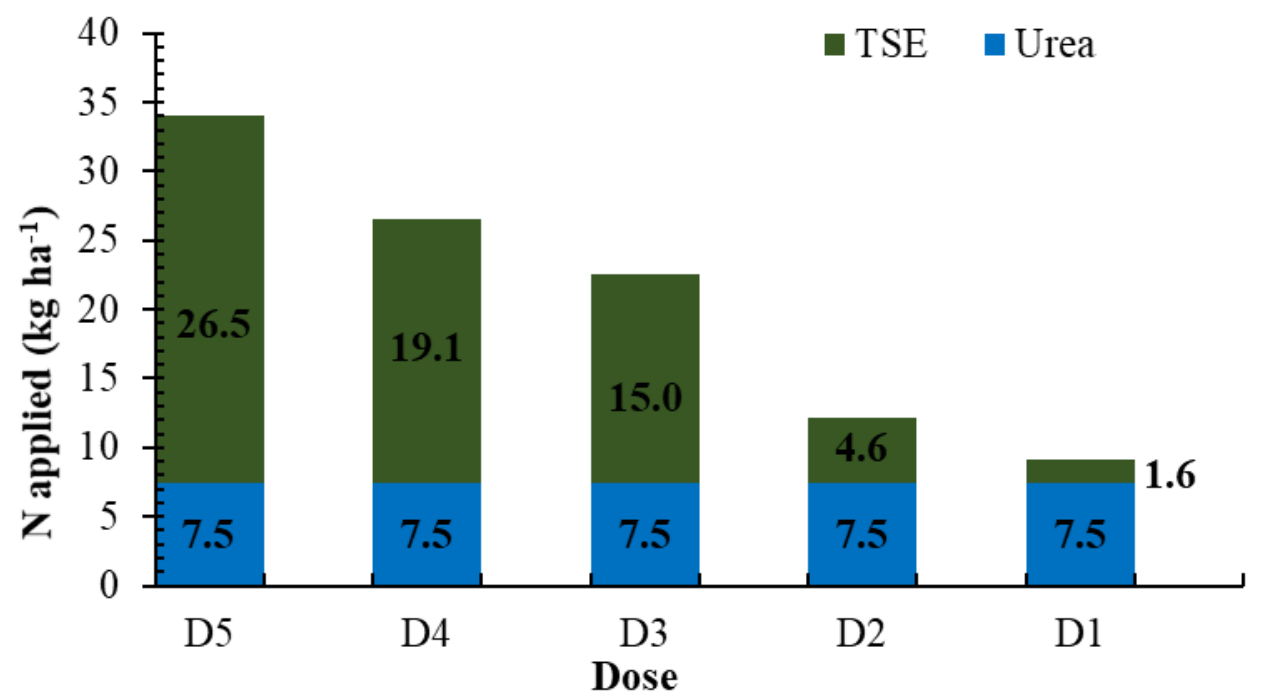

FIGURE 2. Nitrogen dose applied per ton of dry matter produced in the reference treatment $\left(\mathrm{D}_{3} \mathrm{H}_{1}\right)$.

The concentrations of TSE application in water were obtained by a triple-line sprinkler system (Lauer, 1983), where the center line applied TSE and the side lines only water. Thus, the precipitation depth was uniform, but with gradual doses of TSE in water, varying in the direction perpendicular to the sprinkler line, with high concentration near the sprinkler line that applied TSE, until very low concentration near the sprinkler lines that applied only water. The gradual distribution of TSE or water precipitation was determined by previous sprinkler tests performed by Santos et al. (2017).

\section{Effluent}

The TSE was collected at the "Dr. Adelson Taroco" Sewage Treatment Plant, located $1.5 \mathrm{~km}$ from the experimental area. This station is managed by the municipality, which collects and treats the sewage of
Jaboticabal, a city of about 80,000 inhabitants. The effluent was obtained downstream from one of the treatment ponds and pumped through a polyethylene pipe to a $15 \mathrm{~m}^{3}$ reservoir installed next to the experimental area. Water from an artesian well was pumped to another reservoir installed near the experimental area to complement the irrigation of the experiment.

Nutrient analyses in the TSE were performed bimonthly, but nitrogen, $\mathrm{pH}$, and electrical conductivity were monitored monthly. The mean physical and chemical microbiological characteristics of the TSE were: $\mathrm{N}_{\text {Total }}=$ $51.3 \pm 5.76 \mathrm{mg} \mathrm{L}^{-1}, \mathrm{P}=1.2 \pm 0.55 \mathrm{mg} \mathrm{L}^{-1}, \mathrm{~K}=17.9 \pm 1.73$ $\mathrm{mg} \mathrm{L}^{-1}, \mathrm{Ca}=15.6 \pm 2.77 \mathrm{mg} \mathrm{L}^{-1}, \mathrm{Mg}=5.1 \pm 0.94 \mathrm{mg} \mathrm{L}^{-1}$, Total $\mathrm{Fe}_{\text {Total }}=0.4 \pm 0.15 \mathrm{mg} \mathrm{L}^{-1}, \mathrm{Mn}=0.1 \pm 0.04 \mathrm{mg} \mathrm{L}^{-1}$, $\mathrm{Zn}=0.4 \pm 0.21 \mathrm{mg} \mathrm{L}^{-1}, \mathrm{Na}=54.3 \pm 4.26 \mathrm{mg} \mathrm{L}^{-1}$, TOC (total organic carbon) $=36.4 \pm 6.9, \mathrm{pH}=7.1 \pm 0.15$, electrical conductivity $=0.46 \pm 0.024 \mathrm{dS} \mathrm{m}^{-1}, \mathrm{RAS}=2.56 \pm 0.28, \mathrm{CT}$ 
(total coliform) $=409,000 \pm 33,589 \mathrm{MpN}$ (most likely number) $100^{-1} \mathrm{~mL}$ and EC (Escherichia coli) $=9,166 \pm$ 472.5 NMP $100^{-1} \mathrm{~mL}$.

\section{Fertigation, nutritional, and water demand}

Fertigation was applied two to three times a week, following the criterion defined by the nutritional need of the crop or its water demand, which was higher. The treatment $\mathrm{D}_{3} \mathrm{H}_{1}$ was assumed as a reference to adopt, as nutritional demand, the replacement of $22.5 \mathrm{~kg} \mathrm{ha}^{-1}$ of $\mathrm{N}$ per $\mathrm{mg} \mathrm{ha}^{-1}$ of dry mass (DM) of forage produced in each period between forage cuts. This criterion was increased by $50 \%$ in relation to that adopted by Santos et al. (2017), which was based on the recommendation of Vilela et al. (1998). To avoid excess water in the soil due to the high fertigation applications required, part of the $\mathrm{N}$ demand was supplied by urea, applying, immediately after measuring forage productivity, $7.5 \mathrm{~kg} \mathrm{ha}^{-1}$ of $\mathrm{N}$ per ton of dry fodder produced in the treatment $\mathrm{D}_{3} \mathrm{H}_{1}$ and complementing the $15 \mathrm{~kg} \mathrm{ha}^{-1}$ of $\mathrm{N}$ per ton of dry fodder remaining by applying TSE during the next cutting cycle. The same $\mathrm{N}$ dose was applied in the other treatments, in addition to the TSE fraction corresponding to each strategy, as defined in Figure 2. Because concentrations of $\mathrm{P}$ and $\mathrm{K}$ in the TSE are low, these were complemented with triple superphosphate and potassium chloride in all treatments, at doses of 3.5 and $18 \mathrm{~kg} \mathrm{ha}^{-1}$ of $\mathrm{P}_{2} \mathrm{O}_{5}$ and $\mathrm{K}_{2} \mathrm{O}$, respectively, by $\mathrm{mg} \mathrm{ha}^{-1}$ of dry matter produced in the treatment $\mathrm{D}_{3} \mathrm{H}_{1}$, as recommended by Vilela et al. (1998). All fertilizers were distributed manually, two days after each harvest.

Water demand was assumed to be equal to reference evapotranspiration (crop coefficient equal to unit) calculated by the Penman-Monteith equation, parameterized by the FAO-56 method (Allen et al., 1998), with meteorological data from FCAV-UNESP, close to the experiment.

Evapotranspiration was higher than precipitation during the dry period (Figure 3), but there was no water deficit, because fertigation with TSE of $387 \mathrm{~mm}$ had been applied to supply the nutritional demand, in addition to the irrigation of $263 \mathrm{~mm}$ to meet the water demand of the crop in 2015. Fertigation depth with $917 \mathrm{~mm}$ TSE were applied in the RP.

A)

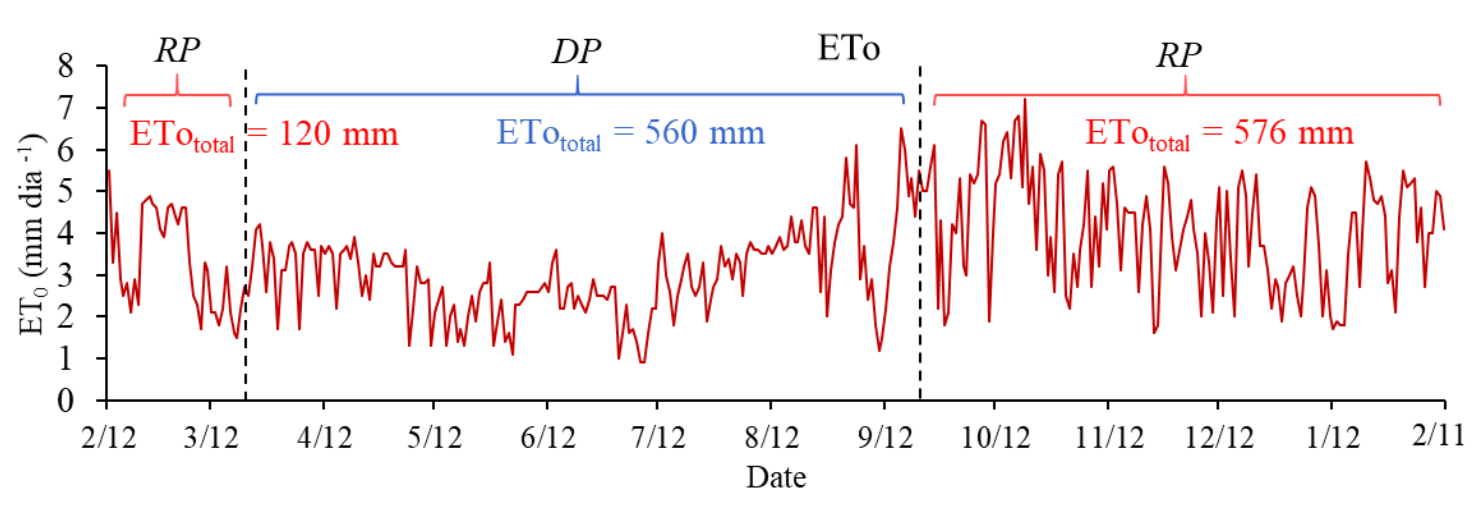

B)

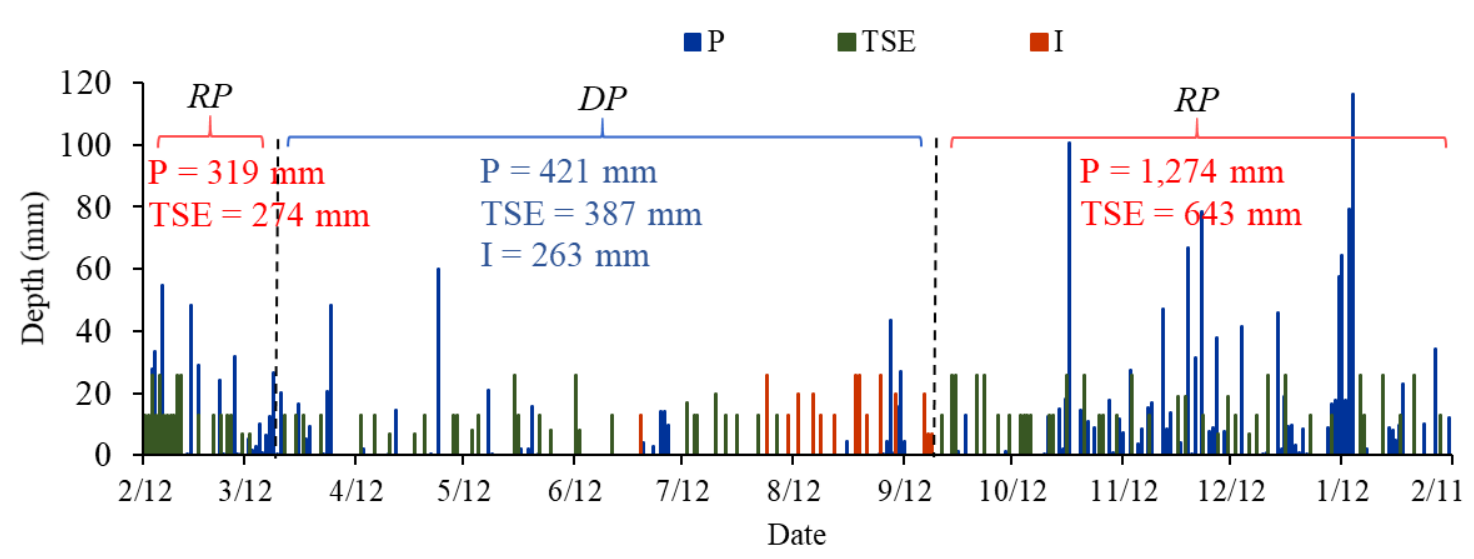

FIGURE 3. Evapotranspiration, precipitation, fertigation and irrigation, in the $2015 / 16$ crop season, in Jaboticabal, SP. A) Reference evapotranspiration $\left(\mathrm{ET}_{0}\right)$ and $\mathrm{B}$ ) precipitation $(\mathrm{P})$, fertigation with treated sewage effluent (TSE) and irrigation (I) during the rainy (RP) and dry (DP) periods.

Fertigation was applied 29 times in the DP and 55 times in the RP (Figure 3B). The total nitrogen applied via TSE + U ranged from 76 to $245 \mathrm{~kg} \mathrm{ha}^{-1}$ in the DP and 169 to $541 \mathrm{~kg} \mathrm{ha}^{-1}$ in RP in the 2015/16 crop, respectively, for treatments with dose $\mathrm{D}_{1}$ to $\mathrm{D}_{5}$ (Table 1$)$. 
TABLE 1. Total nitrogen applied at Urochloa brizantha, in the in the dry period (DP) and rainy period (RP) in 2015/16 crop season, in Jaboticabal, SP.

\begin{tabular}{|c|c|c|c|c|c|c|}
\hline \multirow{3}{*}{ Dose } & \multicolumn{6}{|c|}{ - } \\
\hline & \multicolumn{3}{|c|}{ DP - 2015} & \multicolumn{3}{|c|}{ RP - 2015/16 } \\
\hline & TSE & $\mathrm{U}$ & Total & TSE & $\mathrm{U}$ & Total \\
\hline $\mathrm{D}_{1}$ & 21 & 55 & 76 & 46 & 123 & 169 \\
\hline $\mathrm{D}_{2}$ & 59 & 55 & 114 & 130 & 123 & 253 \\
\hline $\mathrm{D}_{3}$ & 114 & 55 & 169 & 251 & 123 & 374 \\
\hline $\mathrm{D}_{4}$ & 165 & 55 & 220 & 364 & 123 & 487 \\
\hline $\mathrm{D}_{5}$ & 190 & 55 & 245 & 418 & 123 & 541 \\
\hline
\end{tabular}

\section{Weather conditions}

The mean maximum and minimum air temperatures values were $30.8{ }^{\circ} \mathrm{C}$ and $19.9^{\circ} \mathrm{C}$, respectively for $\mathrm{RP}$ and $28.2^{\circ} \mathrm{C}$ and $15.7^{\circ} \mathrm{C}$, respectively, for DP (Figure 4). In the DP, temperatures reached values below $15^{\circ} \mathrm{C}$, a temperature that limits the growth and development of tropical forage grasses (Cooper \& Tainton, 1968).

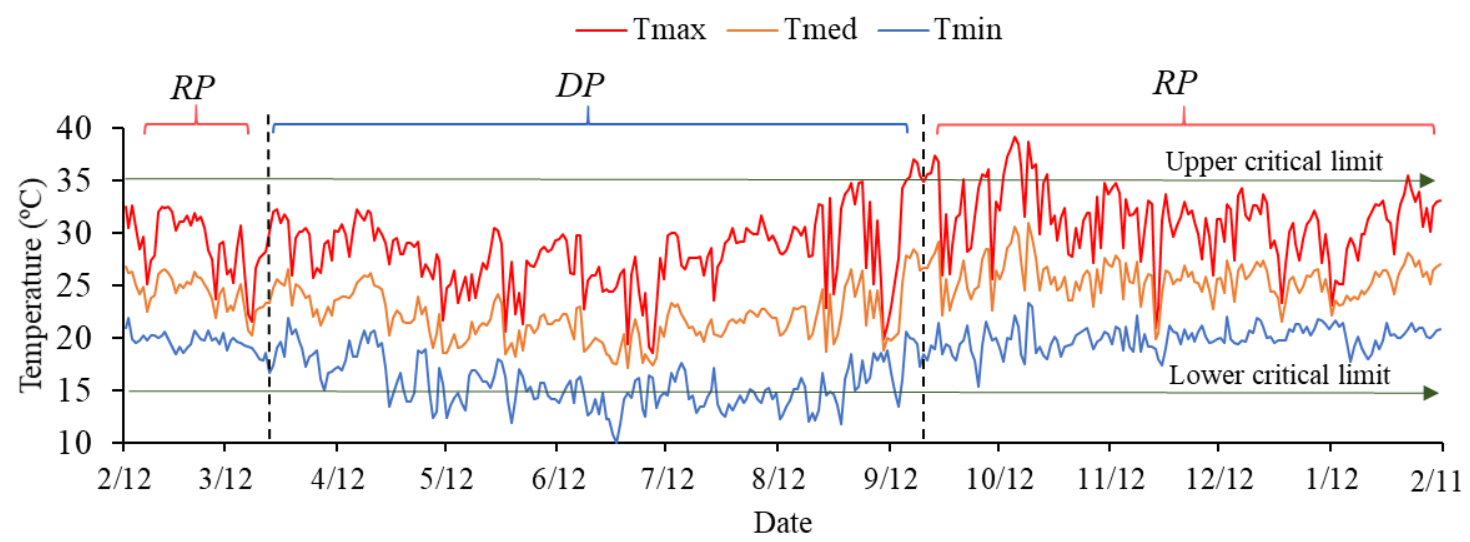

FIGURE 4. Maximum (Tmax), media (Tmed) and minimum (Tmin) temperatures from February, 2015 to February, 2016 , in Jaboticabal, SP.

\section{Crop conduction and evaluations}

The morphogenic and structural characteristics of the forage were evaluated in ten tillers per experimental unit. The choice of the tillers was made with the aid of two wooden rulers $80 \mathrm{~cm}$ long, randomly placed in a representative place of the plot with $60 \mathrm{~cm}$.

For each ruler, five spaced tillers were selected every $20 \mathrm{~cm}$, which were identified with a colored plastic ring. At each data collection cycle, a new group of tillers was selected in other locations of the portion also representative of their average condition. Basal, young, and two to threeleaf completely open were selected.

In the marked tillers, the length of leaf blades and pseudostem was taken with a graduated ruler, twice a week. The length of the expanded leaves was measured from the tip of the leaf to its ligula. In the case of expanding leaves, the same procedure was adopted but considering the ligula of the last expanded leaf as a measurement reference. For senescence leaves, the length was measured between the point to which the senescence process advanced to the leaf ligula (measurement of the green part of the leaf blade). The size of the stem was measured from the soil surface to the ligula of the youngest leaf completely expanded.

From this information, the following morphogenic characteristics were calculated:
- Leaf appearance rate - LApR ( leaf tiller ${ }^{-1}$ day $^{-1}$ ): number of leaves arising per tiller per day;

- Phylochron - Filoc. $\left(\right.$ day $\left.^{-1}\right)$ : inverse of LApR;

- Leaf elongation rate - LEIR ( $\mathrm{cm}$ of leaf tiller ${ }^{-1} \mathrm{day}^{-1}$ ): sum of leaf blade elongation per tiller divided by the number of days of the evaluation period.

- Pseudostem elongation rate - PEIR ( $\mathrm{cm}$ of tiller $\left.{ }^{-1} \mathrm{day}^{-1}\right)$ : sum of all stem elongation and, or, pseudostem, per tiller divided by the number of days of the evaluation period;

- Leaf lifetime - LLD (day): product between LLN and Filoc.

- Leaf senescence rate - LSenR (tiller $\mathrm{cm}^{-1} \mathrm{day}^{-1}$ ): decrease in leaf blade length obtained by the difference between initial and final measurement.

- Number of live leaves per tiller (LLN): ratio of the sum of the number of expanding leaves, expanded, and separable by the number of byes under evaluation.

- Number of dead leaves per tiller (DLN): average number of leaves per tiller with more than $50 \%$ of the leaf blade senescent.

- Final leaf blade length (LBL) (cm): average length of all live leaves, completely expanded, and not grazed on the tiller.

- Pseudostem length (PL) (cm): distance from the soil surface to the youngest leaf ligula completely expanded, including the stem plus the pseudostem. 


\section{Statistical analysis}

The data were grouped into two periods of the year, dry and rainy, that is, for each response variable, the data measured in six months were used to average and generate value only for each period of the corresponding year. Factor analysis was processed by the main components and with varimax rotation method. This is an exploratory multivariate technique that allows understanding the relationships between the original variables explained in terms of a limited number of new variables, called factors, that are the autovectors constructed with the values of the correlation matrix of the original variables with minimal loss of information.

The understanding of involvement as well as the importance of variables in each process consider the values and signals of factor loadings. The factors are linear combinations of the variables studied. The first factor is extracted from the total variation contained in the set of variables while the second is extracted from the remaining variation after eliminating the variation used in the construction of the first, and so on. The factors are independent of each other.

Factor analysis was processed with standardized variables (null mean and unit variance). The Kaiser criterion (self-value greater than or equal to the unit) was used to admit the relevance of the autovectors (Kaiser, 1958).

The effect of the treatment $\mathrm{s}$ with nitrogen dose and cutting height applied in Urochloa brizantha was evaluated with the General Linear Model used as variance analysis (ANOVA). The difference between the levels of the treatments by nitrogen dose and cut-off height were compared with Tukey's multiple comparison mean test ( $\mathrm{p}<$ $0.05)$. All statistical analyses were processed in Statistica software version 7.0 (STATSOFT, 2004).

\section{RESULTS AND DISCUSSION}

The addition of morphogenic characteristics (LApR, LEIR, PEIR, LSenR, Filoc. and LLD) from dry period (DP) to rainy period (RP, Table 2) is a result of favorable air temperature between the critical limit range lower and higher, from $15^{\circ} \mathrm{C}$ to $35^{\circ} \mathrm{C}$, respectively, in RP (Figure 4), increasing the vigor of forage resprout. This increase in the resprout vigor of Urochloa brizantha is due to its physiology $\mathrm{C}_{4}$, according to Labate et al. (1990), they are plants adapted to higher temperatures, so that its photosynthetic rate is improved.

High values of LBL and PL were observed at cutting height $\mathrm{H}_{2}$ (Table 2). These results at the highest cutting height corroborated with those of Medica et al. (2017), since the increase in the cut-off interval provides greater time in free growth, favoring greater LBL and PL. The same author points out that in conditions of fertilization, the Marandu grass under high dose of fertilizer presents longer leaves than the lowest doses of fertilizer, regardless of the cut-off height range, and the same was observed in this study.

Because it has a higher LLD, LSenR decline was observed at cutting height $\mathrm{H}_{1}$ in DP. However, under favorable climatic conditions, as found in PL, the highest cutting height provided increases in LSenR. These results corroborate the conclusions of Costa et al. (2016) and Santos et al. (2011).

Several authors consider LLN as a stable genotypic characteristic in the absence of water and nutritional deficiencies (Martuscello et al., 2005; Santos et al., 2011). For this reason, no increments were observed in the periods and treatments of nitrogen fertilization and cutting height. 
TABLE 2. Morphogenic and structural characteristics of Urochloa brizantha as a function of the nitrogen dose (D) and cutting height $(\mathrm{H})$ applied in the dry and rainy period, in the 2015/16 crop season, in Jaboticabal, SP.

\begin{tabular}{|c|c|c|c|c|c|c|c|c|c|c|}
\hline \multirow{3}{*}{ Strategies* } & \multicolumn{10}{|c|}{ Dry period } \\
\hline & LApR & LEIR & PEIR & LSenR & Filoc. & LLD & LLN & DLN & LBL & PL \\
\hline & \multicolumn{4}{|c|}{------ Leaf tiller ${ }^{-1}$ day $^{-1}$----- } & - day - & \multicolumn{3}{|c|}{------- Number------- } & \multicolumn{2}{|c|}{---- cm ---- } \\
\hline $\mathrm{D}_{1} \mathrm{H}_{1}$ & 0.06 & 0.19 & 0.03 & 0.22 & 15.47 & 47.48 & 3.08 & 0.12 & 11.92 & 9.37 \\
\hline $\mathrm{D}_{2} \mathrm{H}_{1}$ & 0.08 & 0.24 & 0.05 & 0.24 & 12.68 & 42.53 & 3.36 & 0.13 & 13.74 & 9.66 \\
\hline $\mathrm{D}_{3} \mathrm{H}_{1}$ & 0.10 & 0.29 & 0.06 & 0.26 & 9.71 & 34.26 & 3.56 & 0.15 & 15.92 & 11.86 \\
\hline $\mathrm{D}_{4} \mathrm{H}_{1}$ & 0.12 & 0.40 & 0.08 & 0.27 & 8.45 & 30.57 & 3.65 & 0.16 & 17.53 & 13.43 \\
\hline $\mathrm{D}_{5} \mathrm{H}_{1}$ & 0.14 & 0.44 & 0.10 & 0.28 & 7.24 & 27.17 & 3.77 & 0.17 & 17.79 & 13.65 \\
\hline $\mathrm{D}_{1} \mathrm{H}_{2}$ & 0.05 & 0.14 & 0.07 & 0.27 & 19.38 & 56.95 & 2.94 & 0.15 & 14.81 & 12.14 \\
\hline $\mathrm{D}_{2} \mathrm{H}_{2}$ & 0.06 & 0.22 & 0.10 & 0.29 & 17.42 & 56.36 & 3.24 & 0.16 & 18.20 & 13.81 \\
\hline $\mathrm{D}_{3} \mathrm{H}_{2}$ & 0.06 & 0.26 & 0.12 & 0.30 & 15.78 & 55.18 & 3.51 & 0.18 & 21.37 & 17.84 \\
\hline $\mathrm{D}_{4} \mathrm{H}_{2}$ & 0.07 & 0.34 & 0.17 & 0.32 & 14.14 & 50.20 & 3.56 & 0.20 & 25.79 & 22.09 \\
\hline \multirow[t]{2}{*}{$\underline{\mathrm{D}_{5} \mathrm{H}_{2}}$} & 0.09 & 0.40 & 0.22 & 0.34 & 11.69 & 42.78 & 3.67 & 0.21 & 27.58 & 21.06 \\
\hline & \multicolumn{10}{|c|}{ Rainy period } \\
\hline \multirow{2}{*}{$\begin{array}{l}\text { Strategies } \\
\text { driving }\end{array}$} & LApR & LEIR & PEIR & LSenR & Filoc. & LLD & LLN & DLN & LBL & PL \\
\hline & \multicolumn{4}{|c|}{------- Leaf tiller ${ }^{-1}$ day $^{-1}$----- } & \multicolumn{2}{|c|}{---- day ---- } & \multicolumn{2}{|c|}{---- Number ---- } & \multicolumn{2}{|c|}{---- cm ---- } \\
\hline $\mathrm{D}_{1} \mathrm{H}_{1}$ & 0.11 & 0.22 & 0.05 & 0.25 & 8.84 & 27.53 & 3.12 & 0.12 & 13.14 & 11.06 \\
\hline $\mathrm{D}_{2} \mathrm{H}_{1}$ & 0.13 & 0.32 & 0.08 & 0.26 & 7.81 & 26.03 & 3.35 & 0.13 & 14.66 & 11.89 \\
\hline $\mathrm{D}_{3} \mathrm{H}_{1}$ & 0.15 & 0.44 & 0.13 & 0.28 & 6.63 & 23.31 & 3.56 & 0.14 & 18.21 & 12.88 \\
\hline $\mathrm{D}_{4} \mathrm{H}_{1}$ & 0.18 & 0.62 & 0.24 & 0.30 & 5.48 & 20.58 & 3.76 & 0.16 & 19.41 & 14.17 \\
\hline $\mathrm{D}_{5} \mathrm{H}_{1}$ & 0.20 & 0.77 & 0.27 & 0.32 & 5.14 & 19.93 & 3.88 & 0.17 & 19.99 & 13.87 \\
\hline $\mathrm{D}_{1} \mathrm{H}_{2}$ & 0.09 & 0.24 & 0.19 & 0.29 & 11.60 & 38.86 & 3.35 & 0.16 & 18.82 & 19.23 \\
\hline $\mathrm{D}_{2} \mathrm{H}_{2}$ & 0.10 & 0.33 & 0.27 & 0.32 & 10.29 & 34.53 & 3.36 & 0.17 & 20.93 & 21.68 \\
\hline $\mathrm{D}_{3} \mathrm{H}_{2}$ & 0.11 & 0.53 & 0.43 & 0.34 & 9.21 & 33.03 & 3.59 & 0.19 & 23.69 & 23.73 \\
\hline $\mathrm{D}_{4} \mathrm{H}_{2}$ & 0.12 & 0.62 & 0.53 & 0.33 & 8.36 & 31.73 & 3.79 & 0.20 & 26.87 & 24.60 \\
\hline $\mathrm{D}_{5} \mathrm{H}_{2}$ & 0.14 & 0.75 & 0.63 & 0.33 & 7.20 & 28.14 & 3.91 & 0.21 & 24.96 & 21.42 \\
\hline
\end{tabular}

LApR = leaf appearance rate, Filoc. $=$ phyllochron, $\mathrm{LEIR}=$ leaf elongation rate, $\mathrm{PEIR}=$ pseudostem elongation rate, $\mathrm{LLD}=$ leaf life duration, LSenR = leaf senescence rate, $\mathrm{LLN}=$ number of live leaves, $\mathrm{DLN}=$ number of dead leaves, $\mathrm{LBL}=$ leaf blade length and $\mathrm{PL}=\mathrm{pseudostem}$ length.

The processed analyses of factors including the morphogenic and structural characteristics of Urochloa brizantha as a function of applied nitrogen doses and cutting heights allowed the identification of two factors/processes for each period studied, which explained $94.2 \%$ and $94.3 \%$ of the original variance for DP and RP, respectively (Table 3).

\section{Dry period:}

The first factor, responsible for $47.97 \%$ of the original variability (Table 3 ), identified a process with a set of variables (DLN, LSenR, LBL, PL and PEIR) associated with forage mass growth. This process shows a direct correlation between these variables, that is, when the value of one increase (or decreases), the values of the remaining variable will also increase (or decrease).

The second factor, responsible for $46.25 \%$ of the original variability (Table 3 ), identified a process associated with leaf development by the group of variables LLN, LApR, LEIR, Filoc. and LLD. In this process, the variables LLN, LApR, and LElR act directly in leaf development, that is, when the value of one increases (or decreases) the values of the other also will increase (or decrease). Also, the variables Filoc. and LLD acted directly. As the variables LApR, LEIR, and LLN present signs contrary to the Filoc. variables, the LLD has an inverse association, that is, when the value of the variables LApR, LEIR and LLN increase (or decrease) the value of Filoc. vand LLD will decrease (or increase).

The analyses of variance (ANOVA) processed with the scores of factors/processes F1 and F2 (Table 3) revealed that processes $F 1$ and F2 were affected by the interaction of nitrogen dose (D) and cut-off height $(H)(p<0.01)$, showing joint action of the treatments.

With Tukey's mean test of multiple comparisons ( $p$ $<0.05)$, the treatments that obtained the highest growth of forage mass (F1) in Urochloa brizantha were $\mathrm{D}_{5} \mathrm{H}_{2}(1.67)$ and $\mathrm{D}_{4} \mathrm{H}_{2}$ (1.45), which did not differ statistically (Table 4). The lowest forage mass growth was observed in treatments $\mathrm{D}_{1} \mathrm{H}_{1} \quad(-1.44)$ and $\mathrm{D}_{2} \mathrm{H}_{1} \quad(-1.12)$, which also did not statistically differentiate by the mean test.

In the leaf development process (F2) in the DP, the treatments that demonstrated greater and lower leaf development, were $\mathrm{D}_{5} \mathrm{H}_{1} \quad$ (1.75) and $\mathrm{D}_{1} \mathrm{H}_{2} \quad$ (-1.03), respectively, using Tukey's mean test of multiple comparisons $(\mathrm{p}<0.05)$ (Table 4).

\section{Rainy season (RP):}

In the rainy season, the detected processes were practically the same in the dry period with attention to the LLN variable, which in this period becomes a variable belonging to the forage mass growth process. The first factor accounted for $57.9 \%$ and the second for $39.4 \%$ of the 
original variability (Table 3 ).

The ANOVA (Table 3) processed with the scores of factors $F 1$ and $F 2$ revealed that $F 1$ was affected ( $p<0.01$ ) by the nitrogen dose strategy factor (D) and by cutting height (A); there was no interaction for the factors, that is, for this period the dose and cut-off height strategies act independently on F1. However, F2 in this period was affected by the interaction of the factors.

In the Tukey multiple comparison mean test $(\mathrm{p}<$ $0.05)$, the highest forage mass growth (F1) was attributed to the strategies of higher $\mathrm{N}$ dose $(0.75)$ at cutting height $\mathrm{H}_{2}$ (0.71) (Table 4). In the treatments with cutting height $\mathrm{H}_{1}$, the best dose was $\mathrm{D}_{5}$ for the highest forage mass growth, when decreasing the nitrogen dose, the forage mass growth decreased.

The lowest leaf development observed in the mean test was in the treatment $\mathrm{D}_{1} \mathrm{H}_{2}(-1.51)$ (Table 4), while the nitrogen dose increased leaf development. However, at cutting height $\mathrm{H}_{1}$, the highest nitrogen dose favored greater leaf development $\left(\mathrm{D}_{5} \mathrm{H}_{1}\right)$.).

TABLE 3. Summary of factor analysis and ANOVA of forage mass growth and foliar development processes of Urochloa brizantha as a function of treatments in the 2015/16 crop season, in Jaboticabal, SP.

\begin{tabular}{|c|c|c|c|c|}
\hline \multirow[b]{2}{*}{ Variables } & \multicolumn{2}{|c|}{ Dry Period } & \multicolumn{2}{|c|}{ Rainy Season } \\
\hline & Factor 1 & Factor 2 & Factor 1 & Factor 2 \\
\hline \multicolumn{5}{|c|}{ 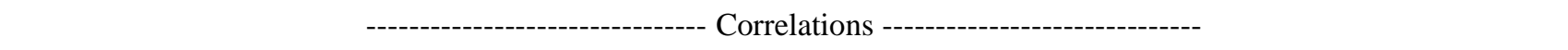 } \\
\hline DLN & 0,97 & 0,17 & 0,98 & $-0,01$ \\
\hline LSenR & 0,97 & 0,01 & 0,94 & 0,05 \\
\hline LBL & 0,97 & 0,08 & 0,96 & 0,00 \\
\hline PL & 0,96 & $-0,06$ & $\mathbf{0 , 8 6}$ & $-0,48$ \\
\hline Sole & $\mathbf{0 , 7 3}$ & 0,63 & 0,95 & 0,01 \\
\hline LLN & 0,50 & 0,79 & 0,73 & 0,60 \\
\hline LApR & 0,00 & 0,98 & 0,01 & 0,99 \\
\hline LEIR & 0,50 & $\mathbf{0 , 8 3}$ & 0,67 & 0,71 \\
\hline Filoc. & $-0,05$ & $-0,98$ & $-0,03$ & $-0,99$ \\
\hline LLD & 0,16 & $-0,98$ & 0,26 & $-0,94$ \\
\hline Proportion (\%) & 47,97 & 46,25 & 54,90 & 39,40 \\
\hline Accumulated (\%) & - & 94,22 & - & 94,30 \\
\hline $\begin{array}{l}\text { Interpretation } \\
\text { (process) }\end{array}$ & $\begin{array}{c}\text { Growth } \\
\text { forage mass }\end{array}$ & Leaf development & $\begin{array}{c}\text { Growth } \\
\text { forage mass }\end{array}$ & Leaf development \\
\hline \multicolumn{5}{|l|}{ ANOVA } \\
\hline Dose (D) & $* *$ & $* *$ & $* *$ & $* *$ \\
\hline Cutting height $(\mathrm{H})$ & ** & ** & ** & ** \\
\hline Interaction D X H & $* *$ & $* *$ & ns & $* *$ \\
\hline
\end{tabular}

LApR = leaf appearance rate, Filoc. $=$ Phyllochron, $L E I R=$ leaf elongation rate, $P E I R=$ pseudostem elongation rate, $L L D=$ leaf life duration, LSenR = leaf senescence rate, $L L N=$ number of live leaves, DLN = number of dead leaves, $L B L=$ leaf blade length and PL $=$ pseudostem length; ** significant $(\mathrm{p}<0.01) ; *$ significant $(\mathrm{p}<0.05)$. 
TABLE 4. Tukey's multiple comparisons test of the forage mass growth and foliar development processes of Urochloa brizantha as a function of the treatments, in 2015/16 crop season, in Jaboticabal, SP.

\begin{tabular}{|c|c|c|c|c|}
\hline \multirow{3}{*}{ Strategies } & \multicolumn{2}{|c|}{ Dry Period } & \multicolumn{2}{|c|}{ Rainy Season } \\
\hline & Factor 1 & Factor 2 & Factor 1 & Factor 2 \\
\hline & $\begin{array}{c}\text { Growth } \\
\text { forage mass }\end{array}$ & Leaf development & $\begin{array}{c}\text { Growth } \\
\text { forage mass }\end{array}$ & Leaf development \\
\hline & \multicolumn{4}{|c|}{ - } \\
\hline $\mathrm{D}_{1} \mathrm{H}_{1}$ & $-1.44 \mathrm{~g}$ & $-0.53 \mathrm{f}$ & -1.62 & $-0.44 \mathrm{fg}$ \\
\hline $\mathrm{D}_{2} \mathrm{H}_{1}$ & $-1.12 \mathrm{gf}$ & $0.01 \mathrm{de}$ & -1.29 & $0.07 \mathrm{e}$ \\
\hline $\mathrm{D}_{3} \mathrm{H}_{1}$ & $0.71 \mathrm{ef}$ & $0.72 \mathrm{c}$ & -0.68 & $0.71 \mathrm{c}$ \\
\hline $\mathrm{D}_{4} \mathrm{H}_{1}$ & $-0.17 \mathrm{~cd}$ & $1.33 \mathrm{~b}$ & -0.14 & $1.31 \mathrm{~b}$ \\
\hline $\mathrm{D}_{5} \mathrm{H}_{1}$ & $-0.07 \mathrm{~cd}$ & $1.75 \mathrm{a}$ & 0.16 & $1.67 \mathrm{a}$ \\
\hline $\mathrm{D}_{1} \mathrm{H}_{2}$ & -0.45 de & $-1.48 \mathrm{~h}$ & -0.21 & $-1.51 \mathrm{i}$ \\
\hline $\mathrm{D}_{2} \mathrm{H}_{2}$ & $0.12 \mathrm{c}$ & $-1.03 \mathrm{~g}$ & 0.19 & $-1.7 \mathrm{~h}$ \\
\hline $\mathrm{D}_{3} \mathrm{H}_{2}$ & $0.72 \mathrm{~b}$ & $-0.70 \mathrm{fg}$ & 0.94 & $-0.69 \mathrm{~g}$ \\
\hline $\mathrm{D}_{4} \mathrm{H}_{2}$ & $1.45 \mathrm{a}$ & -0.35 ef & 1.31 & $-0.32 \mathrm{f}$ \\
\hline $\mathrm{D}_{5} \mathrm{H}_{2}$ & $1.67 \mathrm{a}$ & $-0.28 \mathrm{~d}$ & 1.35 & $0.38 \mathrm{ce}$ \\
\hline Dose & \multicolumn{4}{|c|}{ Average of factorial and - } \\
\hline $\mathrm{D}_{1}$ & -0.95 & -1.00 & $-0.92 \mathrm{e}$ & -0.98 \\
\hline $\mathrm{D}_{2}$ & -0.50 & -0.50 & $-0.55 \mathrm{~d}$ & -0.55 \\
\hline $\mathrm{D}_{3}$ & 0.00 & 0.00 & $0.13 \mathrm{c}$ & 0.01 \\
\hline $\mathrm{D}_{4}$ & 0.64 & 0.50 & $0.58 \mathrm{~b}$ & 0.49 \\
\hline$D_{5}$ & 0.80 & 1.00 & $0.75 \mathrm{a}$ & 1.03 \\
\hline Cutting height & \multicolumn{4}{|c|}{ 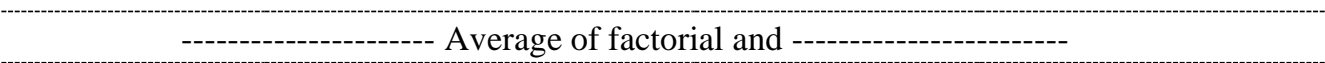 } \\
\hline $\mathrm{H}_{1}$ & -0.70 & 0.65 & $-0.71 \mathrm{~b}$ & 0.66 \\
\hline $\mathrm{H}_{2}$ & 0.70 & -0.65 & $0.71 \mathrm{a}$ & -0.66 \\
\hline
\end{tabular}

*Averages followed by the same lowercase letters within each period do not differ from Tukey's multiple-rate mean test $(\mathrm{p}<0.05)$.

According to Rodrigues et al. (2012), five factors were identified by analyzing factors in creating functional groups with morphogenic and structural characteristics in tropical forages. The first factor was presented as mass development attributed to the variables of leaf appearance rate, leaf elongation rate, number of live leaves, rate of appearance of basilar tiller, and total appearance rate of tillers. These variables were chosen because they have high correlations (fact sheets). The same authors observed the fourth factor as leaf longevity with the variables leaf life duration and leaf senescence rate, similar to this study.

According to Grant et al. (1981), leaf appearance that is expressed by the LApR is determined by two factors: the length of the sheath cartridge that involves the terminal meristem and the LEIR, which respectively determine the distance that the leaf has to travel to emerge and the time with which it travels this distance. Thus, changes in one of these two factors influence the LApR (Sales et al., 2014).

The significant and positive effect of the nitrogen dose on the growth of forage mass under the cutting height $\mathrm{H}_{1}$, provided a greater increase in the LApR, that is, in leaf development (Table 3), because the length of the sheath cartridge was probably balanced, which is represented by the length of the pseudostem, between height of residue (15 $\mathrm{cm})$ and height of cut $\mathrm{H}_{1}(30 \mathrm{~cm})$, which limits the LEIR, both in the RP and in the DP. Some authors (Alexandrino et al., 2010; Duru \& Ducrocq, 2000) did not find this balance, resulting in increased sheath lengthening with increased nitrogen supply, instead of increasing the LApR.
The increase in leaf length and leaf expansion and senescence rates is directly proportional to rest periods, and the reverse occurs in relation to the rate of leaf appearance, observed by Costa et al. (2016) in his study of the morphogenesis of Urochloa brizantha cv. Marandu under different periods of rest. When comparing the increase in the rest period with the increase in the cut-off height, they result in the same response stimulus observed mentioned above.

The highest means in the leaf development process were observed in the cutting height strategies $\mathrm{H}_{1}$ in the highest $\mathrm{N}$ doses, and the lowest averages in the strategies with cut height $\mathrm{H}_{2}$ in the lowest $\mathrm{N}$ dose. LApR is one of the key variables for leaf development. These results corroborate Resende Júnior (2011) who observed that increasing the $\mathrm{N}$ dose at the lowest height provides increments in the LApR. However, at cutting height $\mathrm{H}_{2}$ has higher LLD, resulting in greater leaf longevity. This fact is explained by calculating Filoc. using the inverse of the LApR and the treatments with lower $\mathrm{N}$ dose at the highest cutting height took longer to reach the proposed height, resulting in higher LLD.

\section{CONCLUSIONS}

- Fertigation doses and cutting height for the dry and rainy periods influenced two processes corresponding to forage mass growth (leaf elongation rates, pseudostem, and leaf senescence, leaf lengths and pseudostem, number of dead leaves), called Process 1, and leaf development (leaf appearance rate, number of life sheets, phyllochron and leaf life duration), called Process 2. 
- In Process 1, increasing one of the variables involved in the growth of forage mass increased the other variables.

- In Process 2, increasing one of the variables, such as leaf appearance and number of living leaves, decreased the duration of phyllochron and leaf life, revealing that leaf development is the opposite of leaf longevity to the other.

- The treatment $\mathrm{D}_{5} \mathrm{H}_{2}$ provided superior response to other management strategies in the forage mass growth process in the dry and rainy periods.

- For leaf development, the treatment $\mathrm{D}_{5} \mathrm{H}_{1}$ had a superior response to the other treatments in the dry and rainy periods.

\section{REFERENCES}

Alexandrino E, Vaz RGMV, Santos AC (2010)

Características da Brachiaria brizantha cv. Marandu durante o seu estabelecimento submetida a diferentes doses de N. Bioscience Journal 26(6):886-893.

Allen RG, Pereira LS, Raes D, Smith M (1998) Crop evapotranspiration-Guidelines for computing crop water requirements. FAO Irrigation and drainage paper 56. FAO 300(9):D05109.

Alvares CA, Stape JL, Sentelhas PC, De Moraes G, Leonardo J, Sparovek G (2013) Köppen's climate classification map for Brazil. Meteorologische Zeitschrift 22(6):711-728.

Cezário AS, Ribeiro KG, Santos AS, De Campos Valadares Filho S, Pereira OG (2015) Silages of Brachiaria brizantha cv. Marandu harvested at two regrowth ages: Microbial inoculant responses in silage fermentation, ruminant digestion and beef cattle performance. Animal Feed Science and Technology 208:33-43.

Cooper JP, Tainton NM (1968) Light and temperature requirements for growth of tropical and temperate grasses. Review article. Herbage Abstracts 38:167-176.

Costa NL, Jank L, Magalães JÁ, Fogaça FHS, Rodrigues NA, Santos FJS (2017) Acúmulo de forragem e morfogênese de Megathyrsus maximus cv. Mombaça sob níveis de fósforo. PUBVET 11(11):1074-1187.

Costa NL, Townsend CR, Fogaça FH dos S, Magalhães JA, Seixas Santos FJS de, Rodrigues BHN (2016) Rendimento de forragem e morfogênese de Brachiaria brizantha $\mathrm{cv}$. Marandu sob diferentes períodos de descanso. PUBVET 10(4):271-355.

Duru M, Ducrocq H (2000) Growth and senescence of the successive leaves on a Cocksfoot tiller. Effect of nitrogen and cutting regime. Annals of Botany 85(5):645-653.

Galindo FS, Buzetti S, Teixeira Filho MCM, Dupas E, Ludkiewicz MGZ (2017) Application of different nitrogen doses to increase nitrogen efficiency in Mombasa guinegrass (Panicum maximum cv. mombasa) at dry and rainy seasons. Australian Journal of Crop Science 11(12):1657-1664.
Grant AS, Barthram GT, Torvel L (1981) Components of regrowth in grazed and cut Lolium perenne swards. Grass and Forage Science 36:155-168.

Kaiser HF (1958) The Varimax criterion for analytic rotation in factor analysis. Psychometrika 23:187-200.

Labate CA, Adcock MD, Leegood RC (1990) Effects of temperature on the regulation of photosynthetic carbon assimilation in leaves of maize and barley. Planta 181(4):547-554.

Lauer DA (1983) Line-source sprinkler systems for experimentation with sprinkler-applied nitrogen fertilizers. Soil Science Society of America Journal 47(1):124-128.

Macedo MCM, Zimmer AH, Kichel AN, de Almeida RG, de Araújo AR (2014) Degradação de pastagens, alternativas de recuperação e renovação, e formas de mitigação. In: Embrapa Gado de Corte-Artigo em anais de congresso (ALICE). In: Encontro de Adubação de Pastagens da Scot Consultoria-TEC-FÉRTIL. Bebedouro: Scot Consultoria, Anais... p 158-181.

Marchetti APSME, Dupas E, Ensinas SC, Lourente ERP, Silva EF da, Almeida RG, Carducci CE, Alovisi AMT (2018) Best Management Practices (BMPs) for Nitrogen Fertilizer in Forage Grasses. New Perspectives in Forage Crops 131-148.

Martuscello JA, Fonseca DMD, Nascimento Júnior DD, Santos PMEPS, Ribeiro Junior JI, Cunha DDNFV, Moreira LDM (2005) Características morfogênicas e estruturais do capim-xaraés submetido à adubação nitrogenada e desfolhação. Revista Brasileira de Zootecnia 34(5):1475-1482.

Medica JA, Reis NS, Santos MER (2017) Caracterização morfológica em pastos de capim-marandu submetidos a frequências de desfolhação e níveis de adubação. Ciência Animal Brasileira 18(1):25-29.

Moyo LG, Vushe A, January MA, Mashauri DA (2015) Evaluation of suitability of Windhoek's wastewater effluent for re-use in vegetable irrigation: A case study of Gammams effluent. WIT Trans Ecol Environ 199:109-120.

Resende Júnior AJ (2011) Morfogênese, acúmulo de forragem e teores de nutrientes de Panicum maximum cv. Tanzânia submetido a diferentes severidades de desfolhação e fertilidades contrastantes. Tese Doutorado. Universidade de São Paulo.

Rodrigues CS, Nascimento Júnior DD, Detmann E, da Silva SC, Sousa BDL, da Silveira MCT (2012) Grupos funcionais de gramíneas forrageiras tropicais. Revista Brasileira de Zootecnia 41(6):1385-1393.

Sales ECJ, Reis ST, Rocha Júnior VR, Monção FP, Matos VM, Pereira DA, Aguiar ACR, Atunes APS (2014) Características morfogênicas e estruturais da Brachiaria brizantha $\mathrm{cv}$. Marandu submetida a diferentes doses de nitrogênio e alturas de resíduos. Semina, Ciências Agrárias, 35(5):2673-2684. 
Santos GO, de Faria RT, Rodriguês GA, Dantas GF, Dalri AB, Palaretti LF (2017) Forage yield and quality of marandugrass fertigated with treated sewage wastewater and mineral fertilizer. Acta Scientiarum. Agronomy 39(4):515-523.

Santos HG, Jacomine PKT, Anjos LHC, Oliveira VA, Lumbreras JF, Coelho MR, Almeida JA de, Cunha TJF, Oliveira JB de (2013) Sistema brasileiro de classificação de solos. Brasília, Empresa Brasileira de Pesquisa Agropecuária, 3 ed, 353p.

Santos MER, Da Fonseca DM, Braz TGS, Da Silva SP, Gomes VM, Silva GP (2011) Características morfogênicas e estruturais de perfilhos de capim-braquiária em locais do pasto com alturas variáveis. Revista Brasileira de Zootecnia 40(3):535-542.
Silva VJ, Pedreira CG, Sollenberger LE, Carvalho MS, Tonato F, Basto DC (2016) Growth Analysis of Irrigated 'Tifton 85 ' and Jiggs Bermuda grasses as affected by harvest management. Crop Science 56(2):882-890.

Silva AL, Torres FE, Garcia LL, Mattos EM, Teodoro PE (2014) Tratamentos para quebra de dormência em Brachiaria brizantha. Revista de Ciências Agrárias 37(1):37-41.

STATSOFT (2004) Inc. Statistica (data analysis software system), version 7 .

Vilela L, Soares WV, Sousa DMG, Macedo MCM (1998) Calagem e adubação para pastagens na região do cerrado. Planaltina, DF, Embrapa Cerrados. (Circular Técnica, 37). 